\title{
Employer branding and employee engagement of furniture retailer in Klang Valley
}

\author{
Raemah Abdullah Hashim ${ }^{1}$ and Mohamad Azlan Mohamad Nor ${ }^{2}$ \\ ${ }^{1}$ Open University Malaysia \\ ${ }^{2}$ Open University Malaysia
}

\begin{abstract}
The paper discussed on the relationship between employer branding and employee engagement among employees in selected furniture retailers in Malaysia. This study also looks into the state of employees' engagement and gender differences in their engagement towards their organization. Furniture retailing falls under the retail trade industry that contributed about RM35.7 billion to Malaysia GDP in 2017 with expected growth of 8.7 percent. However, the industry suffers an average yearly employee turnover rate of 13 percent. Amid this high turnover, the raising question is can popularity of employers' branding can result in employee engagement leading to their retention in the organisation. 350 respondents were chosen randomly and $120(30 \%)$ respondents had given feedback on the personally administered questionnaires. The result revealed that there is significant relationship between employer branding and employee engagement. The study also indicated that work challenging is the most important variable which led to drive the employee engagement. Consequently, there is significant difference between male and female in terms of engagement. Organisation, hence may consider leveraging employee engagement which may lead to retaining their employees. Future research may consider researchers to pursue a longitudinal method of research design across a variety of firm-sizes and industries that would be more significant in making generalizations.
\end{abstract}

Keywords: employer branding, employee engagement, Malaysia

\section{Introduction}

The retailing industry in Malaysia is one of the biggest contributors towards Malaysia's gross domestic product (GDP) thus providing employment opportunities for its citizens. According to 2017 Malaysia's Monthly Service Statistic, the retail trade industry had contributed about RM35.7 billion to Malaysia GDP and expected $8.7 \%$ positive growth in that year [31. Currently, retailing industry employs about 700,000 people that constitute about $7 \%$ of the total labour force in Malaysia. Though past studies had characterized the industry into various categories, Ahmad (1980) had group the trade into small scale and large scale. In 1999, one large scale and world's largest furniture retailer had chosen Malaysia to become its regional hub for distribution for its Asia Pacific market. Malaysia was chosen because of the stability and good social environment with talented human resource supply. However, furniture retailer is not without problem. Aside from giving the best customer journey experience and shopping entertaining with friends and family, the industry also face with high employee turnover. Like any other retailing business it was reported that in 2016, the average yearly employee turnover rate was 13 percent [21]. High employee turnover will result in financial loss to the organisation. Replacing talents may likely to cost as much as 25 percent of the company's total annual expenditure in company's compensation [8]. Company without a full force of employees may have their production disrupted [42] . Past studies have indicated that in order to retain employees, employee engagement plays an important role which helps to improve commitment, raising productivity, performance and increase customer satisfaction [39],[32] Truss, Delbridge, Alfes, Shantz and Soane, (2006) conjured that engaged employees generally feel involved, loyal, enthusiastic, and empowered, and thus will exhibit those feelings in their work behaviour. Rasheed et al. (2013) found that engaging employees is very important as they will bring substantial benefits to an organisation such as lowering employee turnover, improving organisational commitment, raising productivity and performance, and increase customer satisfaction. Recent study by Hewitt (2016b) reported in most organisation about 65percent employees are engaged with their organisation while 35 percent are passive or actively disengaged.

So how do business unit like furniture retailing business get their employee engagement? Recent study by Ahmad and Daud (2016) in Malaysian SME-ICT firms found a positive result between engaged employees with

*Corresponding author: raemah_abdullahhashim@oum.edu.my 
employer branding. While other study by Khalid and Tariq (2015) revealed that there is a significant positive relationship between employer branding and facilitated recruiting process. Employer brand usually put forth an image indicating the organisation as a good place to work [53]. Thus this study aims to bridge the gap between the popularity of employer branding and employee engagement among practitioners in the furniture retailing business. Malaysia being a tropical country with abundant of natural tree resources form an important business venture. Lack of academic research on the topic also raises interesting questions for many human resource management scholars. Therefore, the purpose of this research is to find out the relationship between employer branding and employee engagement in furniture retailing company. This study also looks into the state of employees' engagement and gender differences in their engagement towards their organisation.

\section{Literature review}

Employer branding represents an organisational effort to promote and market themselves to be seen differently from their competitors. It has gained in popularity recently and has attracted business leaders' strategy to outshine from others. A brand is a name, symbol, design or a combination of all that identifies the goods or services of one seller or group of sellers, distinguishing them from the goods and services of competitors [12]. Previously, brands were associate with marketing and developing product for corporate brands, however lately it has also linked into human resource management discipline. Consequently, the application of branding values and concepts in human resource management is commonly known now as "employer branding" [5]. Recently, the emerging of the concept has brought business leaders to explore the importance and advantage of employer branding in many fields of human resource management not limiting to just recruitment and engagement but also into talent management and human resource strategy.

Employer branding can also be elucidated as a process of developing the perception of the brand for their audiences and making it unique that could be differentiated from their competitors [49]. This concept has also attracted the interest of many researchers as evident by numerous articles on the topic among business and practitioner. For example Frook (2001) and Berthon et al., (2005) introduced the concept by developing dimensions of employer branding in relation to employer attractiveness while Backhaus and Tickoo (2004) conceptualized and developed research propositions of the employer attraction as a result from employer brand association and employer image.

Employer branding has been first introduced by Barrow (1990). He defined employer branding as a package of functional, economic and psychological benefits for its target audience. Later, another researcher Sullivan (2004) conjured employer branding as "a targeted, long-term strategy to manage the awareness and perceptions of employees, potential employees, and related stakeholders with regards to a particular firm". Just like a traditional brand, an employer branding was identified as having some kind of product/service personality and positioning [9]. This will make the organisation as a desirable product for its employees, hence strongly attracting and motivate the whole internal stakeholder of the organisation. Thus, the organisation are able to retain and motivate while able to attract a pool of talents into the organisation.

Employee engagement on the other hand can be defined in terms of employees' intention to not only achieve organisational goals but will put in superfluous efforts to ensure organisation achieve its vision and mission [25]. Past studies have mooted that positive employees will be an asset to the organisations [24],[27],[18]. According to Ericson (2005), engaged employee is about passion and commitment and willingness to invest oneself and expand one's discretionary effort to help their employers' to succeed. Alfes, Truss, Soane, Rees and Gatenby, (2010) described employee engagement as a state of being positive, manifesting through enthusiastic contributions of intellectual energy, attitudes of optimism and having meaningful relations with others. Robinson, Perryman and Hayday, (2004) depicted it as an optimistic attitude held by a worker manifested in their association and uphold to its principles.

Past studies have indicated that strong employees engagement are related to job resources [6],[34], culture [11],[58],[52] perceived organisational support (POS) [36],[41],[3], leadership [29],[46],[58], job demand [23], rewards [48] and teamwork [4]. Shuck et al. (2011) on the other hand, developed a conceptual model of employee engagement consisting of three (3) variables, namely: job fit, affective commitment, and psychological climate as influences in the development of employee engagement. Conversely, employees' disengagement behavior is divergent or withdrawal employees physically or psychologically from their organisation [32]. Kahn (1990) refers disengagement as withdrawal of an individual during role performance which characterized by a lack of connections between physical, cognitive, and emotional with his job in an organization. Moreover, actively disengage employee can affect on productivity, customer service and performance [35].

Most scholars agree that engaged employees have high levels of energy and contribute strongly to their work through their creativity, responsibility for their own professional development, teamwork and commitment to highquality performance standards [37]. Of recent, Chandani et al. (2016) support this research and stated that an engaged employee is one who produces results, does not change job frequently and more importantly is the ambassador of the company at all times. Thus, the importance of employee engagement has been actively highlighted in all previous research studies and become of the important remedy in organisational success.. 
With regards to relationship to employer branding's and employee engagement, past study by Cascio (2014) had discussed that employer branding is one of the three salient points to retain employees. Human resource professionals believed that organisations could reduce unwarranted voluntary turnover through the development of higher levels of employee engagement [48]. Recent study by Piyachat, Chanongkorn and Panisa, (2015) on 1,349 among employees in Thai petroleum industry found strong positive relationships between employer branding, employee engagement and discretionary effort. Meanwhile, Hewitt (2011) reported that the best employer is differentiated by high level of engagement. This fully supported by past study by Gibbons (2006) who proposed that emotional drivers had four times more impact on individual's engagement than other factors such as pay. Another study conducted by Ahmad and Daud (2016) found a positive relationship between engaged people with employer branding among Malaysian's SME-ICT firms, They also conjured there is significant relationship between the development value in employer branding and turnover intention. Khalid and Tariq (2015) also revealed that there is a significant positive relationship between employer branding and the facilitated recruiting process. Though there are many studies in various industries and had develop theories based on the connection and have reported evidence of organisations expending considerable resources on development of employer brand programme indicating its value [5], however, there is little application on employer branding in relation to employee engagement in furniture retail industry. Therefore, this research main purpose is to elucidate the relationship between employer branding and employee engagement in retail industry specifically among employees in the furniture business. It will be also interesting to find out the state and gender differences in employees' engagement where little attention was given previously with regards to employees engagement in the furniture retail industry. This study supported by Garg (2014), where it was found that there was no distinguishable difference between engagement levels between males and females. Robinson et al. (2004), Schaufeli, Bakker and Salanora(2006) and Yildirim (2008) also concluded the same result of differences being insignificant. Past study on the other hand by Sprang Clark and Whitt-Woosley, (2007), Kong (2009) and Srivastava (2012) indicated that there exist differences in employee engagement between female and male employees in the organisation. Due to the inconsistencies in result and also most of these studies were done outside Malaysia , it will be also interesting to find the differences between genders and also the state of employees in the furniture retail industry engagement towards their organisation.

\section{Methodology}

This study implements descriptive and correlational study design. The target population for this study consisted of 350 employees at executive and store level staff in a selected chain of furniture retail outlet in Klang Valley. The self- administered questionnaires were distributed to all the employees and only 120 (30\%) responded. Data was collected using structured questionnaires made on a scored 5-point Likert continuum from 1 ("strongly disagree") to 5 ("strongly agree"). The structured questionnaire for employee engagement was adapted based on Utrecht Work Engagement Scale (UWES) by Schaufeli and Bakker (2003). The instrument for the employer branding however was adapted from Berthon et al. (2005). The instruments were designed for individual level unit of analysis.

\section{Findings}

Table 4.1 reviews the demographic profiles of the respondent. The sample signified that female respondent (52.5\%) is slightly higher than male (47.5\%).Majority of the respondent were young (54.2\%) aged between 31 - 40 years old. About 60percent respondents have working experience between 1 - 5 years, and 3.3percent respondents have a working experience of $5-10$ years. With reference to working department most of the respondents were from operations department $(45 \%)$ and the rest are from marketing department, human resource department, finance department, being operations department formed the largest department (60\%) of all total manpower of the target retail outlets. With reference race composition, 89.2 percent of the respondents were Malays, 5.8 percent were Chinese, 3.3 percent were Indian and 1 percent was from other races. Based on marital status, majority were single $(57.5 \%)$ and the rest of the respondents are married (42.5\%). With regards to education level, it's almost equal number of respondent between those possessing secondary school certificates (34.2\%) and with Diploma (33.5\%) and degree and above (32.5\%). 
Table 4.1Respondent Profile

\begin{tabular}{|c|c|c|c|}
\hline Item & & Frequency & Percentage \\
\hline Gender & Male & 57 & 47.5 \\
\hline & Female & 63 & 52.5 \\
\hline Age & Below 20 Years & 4 & 3.3 \\
\hline & 21-30 years & 77 & 64.2 \\
\hline & $31-40$ years & 36 & 30.0 \\
\hline & $41-50$ years & 1 & 0.8 \\
\hline & Above 51 years & 2 & 1.7 \\
\hline Working & Below 1 years & 44 & 36.7 \\
\hline & $1-5$ years & 72 & 60.0 \\
\hline & 5-10 years & 40 & 3.30 \\
\hline & Above 10 years & & \\
\hline Department & Marketing & 24 & 20.0 \\
\hline & Human Resource & 8 & 6.7 \\
\hline & Finance & 7 & 5.8 \\
\hline & Operations & 54 & 45.0 \\
\hline & Others & 27 & 22.5 \\
\hline Position & Clerical & 67 & 55.8 \\
\hline & Executive & 44 & 36.7 \\
\hline & Manager & 9 & 7.5 \\
\hline Gender & Male & 57 & 47.5 \\
\hline & Female & 63 & 52.5 \\
\hline & Single & 69 & 57.5 \\
\hline Marital Status & Married & 51 & 42.5 \\
\hline Education Level & Secondary & 41 & 34.2 \\
\hline & Diploma & 40 & 33.3 \\
\hline & Degree and above & 39 & 32.5 \\
\hline
\end{tabular}

Simple linear regression was performed to examine the relationship between employer branding and employee engagement. Assumptions of analysis for evaluation for normality, linearity and homoscedascity were performed. Visual observation of box plot also indicate no serious outlier's setback. Simple regression was then performed since there is no serious violation of assumptions of linear regression.

The result as indicated in Table 4.2 below showed that the employer branding has a positive significant relationship towards employee engagement $(\mathrm{F}=40.26, \mathrm{p}<0.05, \mathrm{R}$ Square $=0.46)$. The result elucidates that employer branding helps to explain $46 \%$ of the variance in employee engagement. Therefore, it can be inferred that the higher is the employer branding, the higher is the employee engagement in retail industry in Klang Valley. The strength of the relationship is considered high of which $r$ value was 0.68 at $p$ value of 0.001 .

Table 4.2 Employer Branding and Employee Engagement

\begin{tabular}{cllll}
\hline Employer Branding & Std. Error & Beta & t & Sig \\
\hline $\mathbf{R = 0 . 6 8}$ & 23.48 & 0.68 & 10.08 & 0.001 \\
$\mathbf{d f = 1 0 1}$ & $\mathrm{R}^{2}=0.46$ & Adjusted R ${ }^{2}=0.45$ & & \\
\hline
\end{tabular}

The state of employee engagement is provided in the following Table 4.3. In the table it clearly indicate that the employees were in agreement where almost all factors related to their engagement with a mean score that was greater than 3.5. The top three highest scores of more than 3.8 were mainly related to: to me, my job is challenging $(\mathrm{mean}=3.891)$, time flies when I'm working (mean=3.867) and I'm enthusiastic about my job (mean=3.858). The three lowest being : It is difficult to detach myself from my job (mean=3.550), when i'm get up in the morning, i feel like going to work $($ mean $=3.575)$ and I'm enthusiastic about my job (mean=3.858). 
Table 4.3 State of employee engagement

\begin{tabular}{|c|c|c|c|}
\hline No & Items & Mean & SD \\
\hline 1 & At my work, I feel bursting with energy & 3.592 & 0.615 \\
\hline 2 & $\begin{array}{l}\text { I find the work that I do full of meaning and } \\
\text { purpose }\end{array}$ & 3.833 & 0.524 \\
\hline 3 & Time flies when I'm working & 3.867 & 0.744 \\
\hline 4 & At my job, I feel strong and vigorous & 3.750 & 0.781 \\
\hline 5 & I'm enthusiastic about my job & 3.858 & 0.781 \\
\hline 6 & $\begin{array}{l}\text { When I'm working, I forget everything else } \\
\text { around me }\end{array}$ & 3.608 & 1.102 \\
\hline 7 & My job inspires me & 3.800 & 0.729 \\
\hline 8 & $\begin{array}{l}\text { When I'm get up in the morning, I feel like } \\
\text { going to work }\end{array}$ & 3.575 & 0.923 \\
\hline 9 & I feel happy when I am working intensely & 3.667 & 0.771 \\
\hline 10 & I'm proud on the work that I do & 3.800 & 0.729 \\
\hline 11 & I'm immersed in my work & 3.608 & 0.748 \\
\hline 12 & $\begin{array}{l}\text { I can continue working for very long periods at } \\
\text { a time }\end{array}$ & 3.675 & 0.852 \\
\hline 13 & To me, my job is challenging & 3.892 & 0.646 \\
\hline 14 & I get carried away when I'm working & 3.650 & 0.837 \\
\hline 15 & At my job, I'm very resilient, mentally & 3.575 & 0.752 \\
\hline 16 & It is difficult to detach myself from my job & 3.550 & 0.878 \\
\hline 17 & $\begin{array}{l}\text { At my work I always persevere, even when } \\
\text { things do not go well }\end{array}$ & 3.583 & 0.693 \\
\hline
\end{tabular}

An independent-samples t-test was performed to examine whether there is any significant differences between male and female employees in the mean score of respondents' engagement towards their organisation. Table 4.4 below shows that is significant differences in scores between male $(M=63.500, S D=9.703)$ and female $(M=56.467, S D=6.046), t=2.437$, $\mathrm{p}=0.021$, two-tailed. The magnitude of the differences in means (mean differences in means $=7.033,95 \%$ confident level: 1.147 to 12.918 ) was moderate (eta squared $=0.5$. Therefore, the Null Hypothesis was rejected indicating there is a significant differences between both male and female employees in their engagement towards work in the retail industry in Klang Valley.

Table 4.4 Differences between Male and Female Engagement

\begin{tabular}{|c|c|c|c|c|c|c|}
\hline Gender & & NN & Mean & & Std. Deviation & Std.Error Mean \\
\hline Male & 57 & & 63.500 & & 9.703 & 2.287 \\
\hline Female & 63 & & 56.467 & & 6.046 & 1.561 \\
\hline Gender & & $\mathrm{t}$ & Sig. & MD & $95 \% \mathrm{CL}$ of & Difference \\
\hline Male & 2.437 & & 0.021 & 7.033 & Lower & Upper \\
\hline Female & & & & & 1.147 & 12.918 \\
\hline
\end{tabular}




\subsection{Conclusion and Discussion}

The result of this research found that there was a positive relationship between employer branding and employee engagement in the furniture retail industry in Klang Valley. This finding supported the view of researchers in other industries like Ahmad and Daud (2016) and Lee, Kim and Kim, (2014). This study is also in line with Piyachat et al. (2015) test on the relationships among employer branding, employee engagement in Thai petroleum industry. Employees most likely feel secured in working for a company that are well known especially if they carry international brand. Therefore, in order for employees to continuously fell relevant they believe they should be more engaged with their work. Most well known brands especially of international standard would have well established human resource practices and policy that will definitely look into the staff welfare.

With regards to the state of engagement, this study found that there were at least three (3) most important elements in employee engagement based on measured variables. Through the identification of these elements the organisation can thus focus and identify the engagement drivers in among their employees and thus able to invest in a strategic plan that can help improve work performance that connect them to business results. Among all the variables, the research has found that work challenging is the most important variable which led to drive the employee engagement. The finding supported Bakker and Demerouti (2008) study which stated that work engagement have as positive, fulfilling, work-related state of mind of employees that can be a characterized as vigor, dedication, and deep absorption of organisational culture. The study characterised vigor by high levels of energy and mental resilience while working. Dedication refers to being strongly involved in one's work and experiencing a sense of significance, enthusiasm, and challenge. Absorption is characterized by being fully concentrated and happily engrossed in one's work, whereby time passes quickly and one has difficulties with detaching oneself from work. In short, engaged employees have high levels of energy and are enthusiastic about their work. Moreover, they are often fully immersed in their work unaware that time flies [44].

This study also found there was significant difference between male and female in terms of engagement. This study did not support past studies by Garg (2014) Robinson et al. (2004), Schaufeli, Bakker and Salanora(2006) and Yildirim (2008), where they found that there was no distinguishable difference between engagement levels between males and females in different industries. However, the results supported Sprang Clark and Whitt-Woosley, (2007), Kong (2009) and Srivastava (2012) studies which showed that there exist differences in employee engagement between female and male employees in various organization setting. The difference of the results however may be influenced by the nature of populations or sampling, type industries or instrument that applies as suggested by past study [44], [24].

This study has its theoretical implications in providing a beginning step to undertake a further research of employer branding and employee engagement in retail industry including possible antecedents and consequences, and determine a much clearer definition of the concept. From the managerial perspectives, the study provides invaluable input to the organisations in engaging their employees through the investment in employer branding. Organisations may consider on some kind of human resource applications or strategy to leverage the employee engagement in either retaining the employees, recruiting the best talent as well as reducing turnover rates or other motivating factors such as giving benefits. By developing a strong value proposition and positioning the employer branding alive in the organisation it may lead to the high level of employee engagement. Future study should consider different settings in warrant generalisations. To increase the robustness of the study a bigger sample size should be considered. Though this study result indicates a good independent variable contributions to the dependent variable, other variables should consider such as job satisfaction, personality types or intention to stay. Researchers should also consider in pursuing a longitudinal method of research design.

\section{References}

1. Ahmad, N. A., \& Daud, S. (2016). Engaging People with Employer Branding.Procedia Economics and Finance, 35 , 690-698.

2. Alfes, K., Truss, K., Soane, C., Rees, C. \& Gatenby, M. (2010). Creating an engaged workforce: findings from the Kingston employee engagement consortium project, available at:www.cipd.co.uk/NR/rdonlyres/DD66E557-DB904F07-8198-87C3876F3371/0/Creating_engaged_workforce.pdf (accessed November 10, 2015).

3. Alvi, K., Abbasi, S. \& Haider, R. (2014). Relationship of perceived organisational support and employee engagement. Science International, 26 , 949-952.

4. Anitha, J. (2014). Determinants of employee engagement and their impact on employee performance. International Journal of Productivity and Performance Management, 63, 308-323.

5. Backhaus, K.,\&Tikoo, S. (2004). Conceptualizing and researching employer branding. Career Development International, 9(5), 501-517.

6. Bakker, A., Schaufeli, W., Leiter, M.\& Taris, T. (2008). Work engagement: An emerging concept in occupational health psychology. Work and Stress, 22 (3), 187-200. 
7. Barrow, S. (1990). Turning recruitment advertising into a competitive weapon. Paper delivered at the CIPD Annual Conference, Harrogate, UK.

8. Bernadette, K. (2007). The Coming Crisis in Employee Turnover. Forbes.

9. Berthon, P., Ewing, M., \& Hah, L. L. (2005). Captivating company: Dimensions of attractiveness in employer branding. International Journal of Advertising, 24(2), 151-172

10. Bhuvanaiah, T. \& Raya, P. (2014). Employee engagement: key to organizational success. SCMS Journal of Indian Management, 11(4), 61-71.

11. Bhuvanaiah, T., \& Raya,R. P. (2015). Mechanism of improved performance: Intrinsic motivation and employee engagement. SCMS Journal of Indian Management, 12(4), 92.

12. Cascio, W. F. (2014). Leveraging employer branding, performance management and human resource development to enhance employee retention. Human Resource Development International, 17(2), 121-128.

13. Chandani, A., Mehta, M., Mall, A., \& Khokhar, V. (2016). Employee engagement: A review paper on factors affecting employee engagement.Indian Journal of Science and Technology, 9(15).

14. Erickson, T. J. (2005), Testimony Submitted Before the US Senate Committee on Health, Education, Labor and Pensions.

15. Frook, J. E. (2001), Burnish your brand from the inside. $B$ to B, Adage, 86, 1-2.

16. Gatenby, M., Rees, C., Soane, E. \&Truss, C. (2009). Employee engagement in context. Chartered Institute of Personnel and Development, London.

17. Garg, N. (2014). Employee engagement and individual differences: A study in Indian context. Management Studies and Economic Systems, 1(1), 41-50.

18. Geldenhuys, M., Laba, K. \& Venter, M. (2014). Meaningful work, work engagement and organisational commitment. SA Journal of Industrial Psychology, 40 ( 1) , 1-10.

19. Gibbons, J. (2006). Employee engagement: A review of current research and its implications. Research Report No. E-0010-06-RR, The Conference Board Inc, New York, USA.

20. Hewitt, A. (2011). 2011 Trends in global employee engagement. Aon Corporation. Retrieved January 2017.

21. Hewitt, A. (2016a). Voluntary turnover rates soar as performance pressure mounts. Press released. Aon Corporation. Retrieved January 2017.

22. Hewitt, A. (2016b). 2016 Trends in global employee engagement. Aon Corporation. Retrieved January 2017.

23. Hicks, R., O’Reilly, G.\& Bahr, M. (2014). Organizational engagement and its driving forces: a case study in a retail travel organization with international outreach. International Journal of Management Cases, 16 (3), 4-19.

24. Kahn, W. A. (1990). Psychological conditions of personal engagement and disengagement at work. Academy of Management Journal, 33(4), 692-724

25. Karsan, R.,\& Kruse, K. (2011). We: How to increase performance and profits through full engagement, john Wiley $\&$ Sons, Inc.

26. Khalid, S., \& Tariq, S. (2015). Impact of employer brand on selection and recruitment process. Pakistan Economic and Social Review, 53(2), 351.

27. Kompaso, M. \& Sridevi, S. (2010).Employee engagement: The key to improving performance. International Journal of Business and Management, 5 (12), 89-96

28. Kong, Y. (2009). A study on the job engagement of company employees. International Journal of Psychological Studies, 1(2), 65-68.

29. Kular, S., Gatenby, M., Rees, C., Soane, E. \& Truss, K. (2008).Employee engagement: A literature review. Working Paper No. 19, Kingston Business School, Kingston University

30. Lee, Y. K., Kim, S., \& Kim, S. Y. (2014). The impact of internal branding on employee engagement and outcome variables in the hotel industry. Asia Pacific Journal of Tourism Research, 19(12), 1359-1380.

31. Malaysian M. S. S. (2017). Sales value of wholesale \& retail trade february 2017. Department of Statistics Malaysia

32. Macey, W. H. \& Schneider, B. (2008). The meaning of employee engagement. Industrial and Organizational Pshchology, 1, 3-30.

33. Macey, W. H., Schneider, B., Barbera, K. M. \& Young, S. A. (2009). Employee Engagement: Tools for analysis, practice and competitive advantage. Malden, WA: Wiley-Blackwell

34. Mauno, S., Kinnunen, U. \& Ruokolainen, M. (2007). Job demands and resources as antecedents of work engagement: A longitudinal study. Journal of Vocational Behavior, Vol. 70 No. 1, pp. 149-171

35. Mone, E., Eisinger, C., Guggenheim, K., Price, B., \& Stine, C. (2011). Performance management at the wheel: Driving employee engagement in organizations. Journal of Business and Psychology, 26(2), 205-212.

36. Pati, P. \& Kumar, P. (2010). Employee engagement: Role of self-efficacy, organizational support and supervisor support. Indian Journal of Industrial Relations, 46(1), 126-137. 
37. Paulsen, N., Callan, J., Ayoko, O. \& Saunders, D. (2013),Transformational leadership and innovation in an R\&D organization experiencing major change. Journal of Organizational Change Management, 26 (3), 595-610

38. Piyachat, B., Chanongkorn, K., \& Panisa, M. (2015). The Relationships among Perceived Employer Branding, Employee Engagement, and Discretionary Effort. วารสารเทคโนโลยีสุรนารี(Suranaree Journal of Social Science), 9(1), 37-60.

39. Rasheed, A., Khan, S., \& Ramzan, M. (2013). Antecedents and consequences of employee engagement: The case of Pakistan. Journal of Business Studies Quarterly, 4(4), 183.

40. Robinson, D., Perryman, S. \& Hayday, S. (2004).The drivers of employee engagement. Institute for Employment Studies Report No. 408, Institute for Employment Studies, Brighton.

41. Saks, M. (2006). Antecedents and consequences of employee engagement. Journal of Managerial Psychology, 21(7), 600-619.

42. Salleh, R., Nair, M. S., \& Harun, H. (2012). Job satisfaction, organizational commitment, and turnover intention: A case study on employees of a retail company in Malaysia. World Academy of Science, Engineering and Technology, 72(12), 316-323.

43. Schaufeli, W.B. \& Bakker, A.B. (2003).UWES - utrecht work engagement scale: Test manual. Department of Psychology, Utrecht University, Utrecht, available at: www.schaufeli.com.

44. Schaufeli, W. B., \& Bakker, A. B. (2004). Job demands, job resources, and their relationship with burnout and engagement: A multi-sample study. Journal of Organizational Behavior, 25 (3), 293-315.

45. Schaufeli, W. B., Bakker, A. B. \& Salanova, M. (2006). The measurement of work engagement with a short questionnaire: A cross-national study. Educational and Psychological Measurement, 66, (4), 701-716.

46. Seijts, G. \& Crim, D. (2006). What engages employees the most, or the ten Cs of employee engagement. Ivey Business Journal, 70 (4), 1-5

47. Shuck, B., Reio, T. G., Jr., \& Rocco, T. (2011). Employee engagement: An antecedent and outcome approach to model development. Human Resource Development International, 14, 427-445. doi:10.1080./13678868.2011.601587.

48. Soemaryani, I. \& Rakhmadini, D. (2013). Work-life balance and organizational culture increating engagement and performance. International Journal of Innovations in Business, 2 (4), 350-372.

49. Sparrow, P. \& L. Otaye (2015), Employee Branding: From Attraction to a Core HR Strategy. White Paper. Lancaster University: Management School.

50. Sprang, G., Clark, J. J. \& Whitt-Woosley, A. (2007). Compassion fatigue, compassion satisfaction, and burnout: Factors impacting a professional's quality of life. Journal of Loss and Trauma, 12 (3), 259-280

51. Srivastava, S. (2012). Enhancing the quality of core work force through employee engagement: An empirical study on managers with respect to gender \& sectoral difference. AIMA Journal of Management \& Research, 6( 2/4).

52. Suharti, L. \& Suliyanto, D. (2012).The effects of organizational culture and leadership style toward employee engagement and their impacts toward employee loyalty. World Review of Business Research, 2 (5), 128-139.

53. Sullivan, J. (2002). Crafting a lofty employment brand: a costly proposition. ER Daily, November 25.

54. Sullivan, J. (2004). Eight elements of a successful employment brand. ER Daily, 23 February, available at: ww.erexchange.com/articles/db/52CB45FDADFAA4CD2BBC366659E26892A.asp (accessed April 14, 2004).

55. Sullivan, S. (1999), The changing nature of careers: A review and research agenda. Journal of Management, 25, 457-75.

56. Truss, C., Delbridge, R., Alfes, K., Shantz, A. \& Soane, E. (Eds). (2004). Employee engagement in theory and practice. Agingdon: RoutledgeTaylor\& Francis Group.

57. Yildirim, I. (2008). Relationships between burnout, sources of social support and socio demographic variables. Social Behavior and Personality, 36 (5), 603-616.

58. Zhu, W., Avolio, J. \& Walumbwa, O. (2009). Moderating role of follower characteristics with transformational leadership and follower work engagement. Group \& Organization Management, 34 (5)590-619. 